\title{
Higher Education Performance Measurement Based on Mutual Contribution
}

\author{
I N. Sutapa, Zeplin J. H. Tarigan, Jenny M. Djundjung, and J. Rahardjo
}

\begin{abstract}
The article discusses a measurement model to overcome a problem of performance among higher education institutions and its lecturers which is less support each other. The model aims to increase lecturer's motivation which can improve the performance of the higher education organizations and vice versa. The research method to develop the performance measurement is a focus group discussion, was done by inviting higher education top management and senior lecturers to discuss the mutual contribution each other. The finding of this research is a performance measurement model which are a tiered, balanced, and shared a mutual contribution. Tiered measurements are done in stages, starting from measuring the performance of individual lecturers upward to the measurement of institution performance. A balanced was done by measurement based on the Balanced Scorecard concept. Mutual contribution among lecturers and their institution, as measured by share the performance of institution to its lecturers and the other hand, all lecturers' performance are accumulated to institution performance.
\end{abstract}

Index Terms-Mutual contribution, higher education, performance measurement, and balanced scorecard.

\section{INTRODUCTION}

The role of lecturers to improve the quality of higher education is increasingly important. They are central to managing the teaching and learning process. On the other hand, the role of management and leaders of higher education institutions in managing the implementation of teaching and learning process is also essential. They support the need for resources to ensure the learning process runs effectively.

Measuring the performance of higher education institutions needs to take into account the role of individual lecturers individually, the collective role of all lecturers, as well as the management and leadership performance of institutional leaders, so that individual lecturers' expectations, collective lecturer expectations, and institutional leadership goals are accommodated.

In measuring the performance of higher education, in addition to paying attention to the object or unit to be measured, need to pay attention to indicators measured [1]. The measured indicators should have a significant impact on

Manuscript received April 20, 2018; revised May 22, 2018. This work was supported in part by Kemenristekdikti Indonesia under Grant Hibah PUPT.

I N. Sutapa and J. Rahardjo are with the Industrial Engineering Department, Petra Christian University, Surabaya 60236, Indonesia (e-mail: mantapa@petra.ac.id,jani@petra.ac.id).

Zeplin J. H. Tarigan is with the Post Graduate Program of Management, Petra Christian University, Surabaya 60236, Indonesia (e-mail: zeplin@petra.ac.id).

Jenny M. Djundjung is with the English Department, Petra Christian University, Surabaya 60236, Indonesia (e-mail: jennymd@ petra.ac.id). institutional performance. The primary performance indicator that is widely used to measure the success of the company is an indicator capable of translating the vision-mission of higher education into real action, which is based on the concept of Balanced Scorecard.

The design of performance measurement of higher education institution (HE) based on Balanced Scorecard, developed by translating $\mathrm{HE}$ vision and mission into action in four perspectives namely financial, customer, internal business process, and learning and growth perspective [1], [2]. In practice, vision and mission are very slow and often fail to translate into actions to improve performance, due to weak of lecturer commitment, as well as heads of study programs, deans, and rectors [3]. Maybe the reason was individual performance are generalized as average score in one work unit, high and low achievers get the same rewards. Also, their contribution to the organization is directly or indirectly to the progress of the organization is not adequately rewarded [4].

This research seeks to overcome these difficulties by rewarding them according to their contributions and by the level of performance of their organizations. Smith et al. [5] state that a company's performance is an aggregation of the performance of various main activities that differ from several aspects of the business. Furthermore, the assessment of the business performance of the firm as a whole is the total multiplication of the performance scores of the aggregate performance activities.

In this article, the HE performance assessment is not only based on the aggregation of the performance of various main activities that differ from several aspects of the business but also based on the contribution of the individual performance of individual members of the company. Also, individual performance appraisals are based not only on individual performance appraisals but also on the assessment of their organizations (HE institution or HEI). There is a mutual valuation; individuals contribute aggregate to firm valuation, another hand institutions also contribute additionally to an individual's performance appraisal. And, the calculation of the total score of an HE institution performance is based on the sum of the performance score of each major activity multiplied by the weight of the activity.

\section{RESEARCH METHOD}

In the design of this performance measurement system, data collection techniques used Focus Group Discussion (FGD) and design validation are done with confirmation and in-depth interviews with unit and college leaders. FGD is a 
qualitative data collection technique with the aim of discovering the meaning of a theme according to a group's understanding. Characteristic of FGD is an interaction between researcher with an informant (unit leader and college) and an informant with another informant [6]. FGD in this design aims to obtain a relationship between the performance of individual lecturers with the performance of higher education institutions, individual contributions to the performance of institutions of higher education, and the contribution of higher education institutions to individual performance. In this discussion, a balanced and mutually beneficial performance measurement system for both parties is sought. FGDs were repeatedly conducted between researchers and informants, i.e., unit leaders and college leaders. In each FGD attended a maximum of 12 people.

\section{DESIGN OF HEI's MEASUREMENT SYSTEM}

Design of a system of mutual performance measurement, the contribution between $\mathrm{HE}$ institution performance and individual performance. The performance of HE institutions is the result of performance appraisal of organizational activity in teamwork aggregated with individual performance individually. Organizational performance is assessed as a management and leadership performance of the organization's leaders. Meanwhile, individual performance is judged by individual performance combined with the organization's performance value.

The mutual contribution is measured in stages, as illustrated in Fig. 1.

Fig. 1 shows a Tiered Performance Measurement system. In Fig. 1 presented the concept of tiered performance measurement, starting from the smallest level (individual, unit) to the largest that is the institution of higher education. Assessment from the smallest to the largest level using the concept of accumulation or aggregation, the lower units must cooperate and support the performance of the unit or organization above. Meanwhile, as a consequence, from top to bottom is control by superiors to the units under it, the leadership carries out the leadership and management of the units under it.

HE Performance is measured by the lecturer's performance as the smallest unit, then the measurement of all the lecturers is accumulated into the measurement of the study program, place where the lecturers are gathered. Also, there are measurements of the study program which is the result of the achievement of all lecturers who cannot be measured individually. Measurement of this study program is a measure of leadership and organizational management by the leader of the study program, as a form of leadership performance and organizational management, in directing and managing lecturers in the study program. Furthermore, the performance scores of all study programs under the faculty, plus the performance achievements of faculty that cannot be measured as separate achievements of each lecturer and undergraduate program, are accumulated into the faculty's performance score. This sharing score means that the achievements of all lecturers and study programs under the control of a faculty are achieved because of leadership and management of faculty leaders.

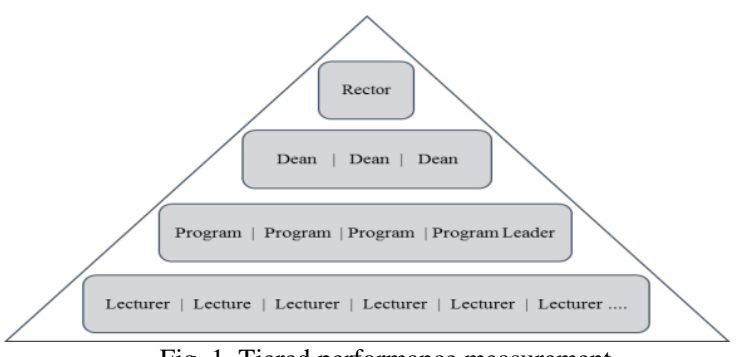

Fig. 1. Tiered performance measurement.

Table I presents a system and method of measuring mutual performance. The performance of individual lecturers, study program leaders, faculty leaders (dean), and college leaders (rector) is measured in four Balanced Scorecard perspectives: financial perspective, stakeholder satisfaction, internal business processes, and learning and growth perspectives. Each perspective is measured using several key performance indicators (KPIs). Those KPIs derived from the elements of accreditation measurement of study programs and institutions of higher education refers to the College Accreditation Board, university strategic plan, and refer to some clauses of ISO 9001 Quality Management System. Following the concept of tiered in Figure 1, performance will be measured from bottom to top level. KPIs on an individual lecturer or unit will be accumulated or aggregated to the above (in the table are marked as " $\rightarrow$ "), his/her/their organizations as a contribution of her/his/their performance. Individuals or leaders at the above levels gain an accumulated score from below, due to managerial and leadership work. Meanwhile, from top to bottom, the performance results of unit/organization leaders, in managing and leading their subordinates, will be shared into members of the unit/organization as a result of teamwork (in the table are marked as " $\leftarrow$ "). Individuals/units under or as members of a unit/organization get a particular part of the unit/organization performance in recognition of mutually supportive teamwork.

KPIs for lecturers, programs, faculty, and university level distributed in 4 BSC perspectives derived from FGDs using reference [4], [7]-[10]. The weight of the entire KPI is based on the college policy.

\section{CONCLUSION}

A performance measurement system and method have been developed to provide performance-based rewards to individual lecturer achievements, leaders of study program/faculty/university for managerial and leadership work. These systems and methods are based on tiered and mutual concepts. The performance of the individual or unit leader member of/under an organization be accumulated the performance of his/her/organization, as a form of commitment and responsibility to the organization. Otherwise, the performance of the organization is distributed/shared to the individual of the organization members as a form of appreciation for their contribution to the organization. 
TABLE I: MUtuAL CONTRIBUtion PERFoRMANCE MEASUREMENT SCHEME WITH KPI BASED ON BSC

\begin{tabular}{|c|c|c|c|c|}
\hline \multirow{2}{*}{$\mathrm{BSC}$} & \multicolumn{4}{|c|}{ KPIs } \\
\hline & Lecturer & Program Study & Faculty & HEI \\
\hline \multirow{7}{*}{ 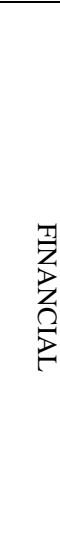 } & Research grants & $\rightarrow$ & $\rightarrow$ & $\rightarrow$ \\
\hline & $\begin{array}{l}\text { Intellectual } \\
\text { properties }\end{array}$ & $\rightarrow$ & $\rightarrow$ & $\rightarrow$ \\
\hline & $\begin{array}{l}\text { Earnings from } \\
\text { training }\end{array}$ & $\rightarrow$ & $\rightarrow$ & $\rightarrow$ \\
\hline & Consulting's income & $\rightarrow$ & $\rightarrow$ & $\rightarrow$ \\
\hline & $\leftarrow$ & F & $\leftarrow$ & $\begin{array}{l}\text { Tuition } \\
\text { fees }\end{array}$ \\
\hline & $\leftarrow$ & $\begin{array}{l}\text { Industry and } \\
\text { alumni grants }\end{array}$ & $\rightarrow$ & $\rightarrow$ \\
\hline & $\leftarrow$ & $\leftarrow$ & $\leftarrow$ & $\begin{array}{l}\text { Gover- } \\
\text { ment } \\
\text { grants }\end{array}$ \\
\hline
\end{tabular}

\begin{tabular}{|c|c|c|c|c|}
\hline & $\begin{array}{l}\text { Student satisfaction } \\
\text { to lecturers }\end{array}$ & $\rightarrow$ & $\rightarrow$ & $\rightarrow$ \\
\hline \multirow{5}{*}{ 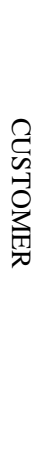 } & $\leftarrow$ & $\begin{array}{l}\text { Student } \\
\text { satisfaction to } \\
\text { study program }\end{array}$ & $\rightarrow$ & $\rightarrow$ \\
\hline & $\leftarrow$ & $\leftarrow$ & $\leftarrow$ & $\begin{array}{l}\text { Student } \\
\text { satis- } \\
\text { faction } \\
\text { to HEI }\end{array}$ \\
\hline & $\leftarrow$ & $\begin{array}{l}\text { Program } \\
\text { accreditation }\end{array}$ & $\rightarrow$ & $\rightarrow$ \\
\hline & $\leftarrow$ & $\leftarrow$ & $\leftarrow$ & $\begin{array}{l}\text { HEI ac- } \\
\text { credita- } \\
\text { tion }\end{array}$ \\
\hline & $\begin{array}{l}\text { The academic } \\
\text { community and } \\
\text { industry awards }\end{array}$ & $\rightarrow$ & $\rightarrow$ & $\rightarrow$ \\
\hline \multirow{8}{*}{ 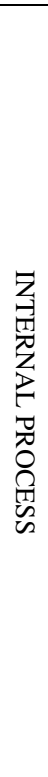 } & $\leftarrow$ & $\begin{array}{l}\text { Student's cum } \\
\text { performance }\end{array}$ & $\rightarrow$ & $\rightarrow$ \\
\hline & $\leftarrow$ & $\begin{array}{l}\text { Graduation on } \\
\text { time }\end{array}$ & $\rightarrow$ & $\rightarrow$ \\
\hline & $\leftarrow$ & $\begin{array}{l}\text { Students } \\
\text { dropouts }\end{array}$ & $\rightarrow$ & $\rightarrow$ \\
\hline & $\begin{array}{l}\text { Research } \\
\text { performance }\end{array}$ & $\rightarrow$ & $\rightarrow$ & $\rightarrow$ \\
\hline & $\begin{array}{l}\text { Community service } \\
\text { performance }\end{array}$ & $\rightarrow$ & $\rightarrow$ & $\rightarrow$ \\
\hline & $\leftarrow$ & $\begin{array}{l}\text { Program } \\
\text { output/outcome }\end{array}$ & $\rightarrow$ & $\rightarrow$ \\
\hline & $\leftarrow$ & $\leftarrow$ & $\begin{array}{l}\text { Program } \\
\text { out/ } \\
\text { outcome }\end{array}$ & $\rightarrow$ \\
\hline & $\leftarrow$ & $\leftarrow$ & $\leftarrow$ & $\begin{array}{l}\text { Program } \\
\text { output/ } \\
\text { outcome }\end{array}$ \\
\hline \multirow{5}{*}{ 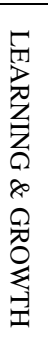 } & Education level & $\rightarrow$ & $\rightarrow$ & $\rightarrow$ \\
\hline & Academic position & $\rightarrow$ & $\rightarrow$ & $\rightarrow$ \\
\hline & $\begin{array}{l}\text { Professional } \\
\text { certification }\end{array}$ & $\rightarrow$ & $\rightarrow$ & $\rightarrow$ \\
\hline & $\leftarrow$ & $\leftarrow$ & $\begin{array}{l}\text { Lecturer } \\
\text { exper- } \\
\text { tise }\end{array}$ & $\rightarrow$ \\
\hline & $F$ & $\leftarrow$ & $\leftarrow$ & $\begin{array}{c}\text { IT infra- } \\
\text { structur } \\
\mathrm{e}\end{array}$ \\
\hline
\end{tabular}

\section{REFERENCES}

[1] F. F. Al-Hosaini and S. Sofian, "A review of balanced scorecard framework in higher education institution (HEIs)," International Review of Management and Marketing, vol. 5, no. 1, p. 26, 2015.

[2] A. R. Ahmad and N. K. Soon, "Balanced scorecard in higher education institutions: What should be consider?" presented at International Symposium on Technology Management and Emerging Technologies, Langkawi, Kedah, Malaysia, 2015.

[3] N. Rompho, "Why the balanced scorecard fails in SMEs: A case study," International Journal of Business and Management, vol. 6, no. 11, p. 39, 2011.

[4] I N. Sutapa, Z. J. H. Tarigan, and J. Mochtar, "Influence of e-standard operating procedure to auditor satisfaction through IT capabilities and e-audit," in Proc. $20173^{\text {rd }}$ International Conference on Industrial and Business Engineering, Sapporo, Japan, 2017.

[5] M. W. Smith, A. Apfel, and K. Bergstrom, Methods and Systems for Evaluation of Business Performance, U. S. Patents no. US20040068431 A1, 2004.

[6] R. Kraaijvanger, C. J. M. Almekinders, and A. Veldkamp, "Identifying crop productivity constraints and opportunities using focus group discussions: A case study with farmers from Tigray," NJAS-Wageningen Journal of Life Sciences, vol. 78, p. 139, 2016.

[7] H. Tohidi, A. Jafari, and A. A. Afshar, "Using balanced scorecard in educational organizations," Procedia Social and Behavioral Sciences, vol. 2, p. 5544, 2010.

[8] A. Erkollar and B. Oberer, "Lecturer connections: The multidimensional team management scorecard," Procedia Economics and Finance, vol. 26, p. 942, 2015.

[9] M. Madanchian, N. Hussein, F. Noordin, and H. Taherdoost, "Leadership effectiveness measurement and its effect on organization outcomes," Procedia Engineering, vol. 181, p. 1043, 2017.

[10] Y. Samian and N. M. Noor, "Students' perception on good lecturer based on lecturer performance assessment," Procedia -Social and Behavioral Sciences, vol. 56, p. 783, 2012.

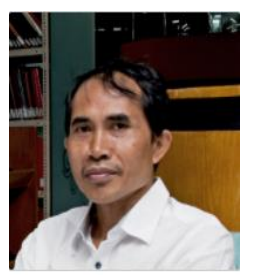

I N. Sutapa was born in Bali, Indonesia in 1968. He graduated from industrial mathematics of Universitaet Kaiserslautern, Germany and the doctorate of operation management from Brawijaya University, Malang, Indonesia. $\mathrm{He}$ is a full-time lecturer in the Industrial Engineering Department, Petra Christian University Surabaya Indonesia since 1993. The courses he teaches range from calculus, operational research, lean manufacturing, quality management system, and performance management. His research interest is the mathematical model for inventory, supply chain, and decision making, performance measurement system, and quality improvement.

Zeplin J. H. Tarigan is a full lecturer in Graduate Program of Management at Petra Christian University, Surabaya, Indonesia, since 2006. He graduated from Management Technology of Institut Technology Sepuluh Nopember Surabaya, Indonesia, and a doctorate of Management Science from Brawijaya University, Malang, Indonesia. Previously, he worked as a Production Planning and Inventory Control manager in several major companies in Indonesia. He is also a consultant for production and inventory planning, ERP, and quality management system. The courses he teaches range from production and operation management, project management, management information system, and enterprise resources planning. His research interest in enterprise resources planning and performance management.

Jenny M. Djundjung is a full-time lecturer in the English Department of Petra Christian University, Indonesia since 1985. She obtained her MA in Literature from Arizona State University and her Doctorate, also in Literature, from the University of Indonesia. The courses she teaches range from culture to literature: Public Speaking, British Studies, Australian Studies, Drama, Popular Literature, Literature and Gender. Her research interest lies in Indonesian popular literature, popular culture and gender studies and she has published and presented papers in these areas in journals and in national and international conferences.

J. Rahardjo was born in Surabaya, Indonesia in 1962. He graduated from Management Technology of Asian Institute of Technology, Bangkok 
Thailand and a doctorate of Advanced Manufacturing Technology from Universiti Teknologi Melaka, Malaysia. He is a full-time lecturer in the Industrial Engineering Department, Petra Christian University Surabaya, Indonesia since 1989. The courses he teaches range from Statistical Methods, Statistical Quality Control, Quality Management System, Six Sigma, Decision Analysis, and Management Technology. His research interest lies in decision making using AHP, quality process improvement, processes design, and innovation process, and advanced manufacturing technology for SME. He also serves as a consultant of process innovation and improvement, quality management system, and six sigma for some companies in Indonesia. 